\title{
Adaptation of the rat to a low-protein diet: the effect of a reduced protein intake on the pattern of incorporation of $L-\left[{ }^{14} \mathrm{C}\right] l y$ sine
}

\author{
By J. C. WATERLOW* AND JOAN M. L. STEPHEN* \\ Medical Research Council Tropical Metabolism Research Unit, \\ St Mary's Hospital, London, $W_{2}$
}

(Received I4 September 1965-Accepted 8 February 1966)

\begin{abstract}
I. Rats were chronically depleted of protein by being kept on a $6 \%$ casein diet for 5 -8 weeks. Control rats were fed on a normal diet. Both groups were injected intraperitoneally with $\mathrm{L}-\left[\mathrm{U}-{ }^{14} \mathrm{C}\right]$ lysine. Some rats from each group were then put on a protein-free diet to produce acute depletion. The animals were killed 3 days after the injection. 2 . The organs and tissues were analysed for total nitrogen and radioactivity. Free lysine, total amino $\mathbf{N}$ and specific activity of free lysine were measured in muscle, liver and serum. The total muscle mass of the animals was determined. Samples of muscle and skin were fractionated and the sp. ac. of the fractions was measured. 3. The main loss of $\mathrm{N}$ in acute depletion was found in the viscera and carcass residue; the percentage of total body $N$ contributed by muscle was increased in protein-depleted rats. 4 . The depleted rats retained relatively more radioactivity in the internal organs and less in the carcass than normal rats. 5. The ratio of the sp. ac. in protein-bound lysine to the sp. ac. of free lysine showed that protein synthesis was reduced in the muscle of the protein-depleted rats, although there was no decrease in the amount or sp. ac. of free lysine even in severe depletion. 6. Sarcoplasmic and fibrillar proteins of muscle were equally affected by protein depletion, but there was some indication of a preferential decrease in protein synthesis in one of the skin fractions. 7 . The results for muscle protein are compared with those given in the literature for liver proteins. It is suggested that the rat adapts to a low-protein intake by an alteration in the pattern of protein synthesis.
\end{abstract}

When a rat is given a single dose of a labelled amino acid the distribution of the label between the different organs and tissues of the body is dependent upon the dietary state of the animal. For example, 3 days after the injection of DL- $\left[{ }^{35} \mathrm{~S}\right]$ methionine, in normal rats $75 \%$ of the radioactivity recovered was found in the carcass (muscle, skeleton and skin), $25 \%$ in the internal organs. In rats on a low-protein diet these proportions were different; nearly $50 \%$ of the radioactivity recovered was in the viscera (Waterlow, I959).

Many previous workers have shown in experiments with labelled amino acids that in animals on a low-protein diet liver protein becomes more highly labelled than in controls on a normal diet. Muscle protein tends to be less highly labelled, although the figures are rather variable (Solomon \& Tarver, 1952; Bendicenti, Mariani, Paolucci \& Spadoni, 1959; Schreier \& Kazassis, ı960; Gaetani, Mariani, Spadoni \& Tomassi, I961; Muramatsu, Sato \& Ashida, I963). In most of these experiments the results have been expressed in terms of specific activity of protein, and the sizes of the protein pools-liver mass and muscle mass-have not been measured. If these quantities are also known, a more comprehensive picture is obtained of the amino acid uptake in the animal as a whole.

* Present address: Medical Research Council Tropical Metabolism Research Unit, University of the West Indies, Mona, Kingston 7, Jamaica. 
It is convenient to consider liver and muscle as two representative tissues which show opposite changes in response to protein deficiency. The question to be answered is whether these differences in uptake represent real differences in rates of protein synthesis. It is well recognized that conclusions about rates of protein synthesis cannot be drawn from isolated measurements of protein specific activity. It is necessary also to know the specific activity of the free amino acid precursor, and how it changes with time. A further complication is that when measurements are made on crude tissue proteins the composition of the tissues may not be the same in the groups of animals being compared, since a low-protein diet may cause selective loss of one or more types of protein. A classical example is the reduction in concentration of plasma albumin, but not of plasma globulins, produced by protein deficiency both in animals and in man (Waterlow, Cravioto \& Stephen, 1960).

In the experiments to be presented we have been concerned mainly with muscle, which, as the largest protein mass in the body, is of especial nutritional interest. We have tried to determine whether the reduced uptake of labelled amino acid by muscle in protein-depleted rats could be accounted for either by changes in the specific activity of the free amino acid, or by changes in the relative amounts and activities of the two main muscle fractions, sarcoplasmic and fibrillar proteins. Some observations have also been made on skin, which in the rat contains $25-30 \%$ of the total body nitrogen.

In almost all these experiments the amino acid used was lysine. Most of the measurements were made 3 days after injection of the labelled amino acid, because it was found in previous work that this was the time interval at which differences in incorporation were most marked between normal and protein-depleted animals (Waterlow, 1959). During these 3 days the specific activity of muscle protein rises, whereas that of the liver, plasma and internal organs falls after about the first $6 \mathrm{~h}$. For investigating the changes in the liver a different experimental programme would be needed, over a shorter time period. Experiments of this type have been made by Spadoni and her colleagues (Gaetani et al. 196I). Their results are complementary to ours, and will be considered in more detail in the discussion.

\section{EXPERIMENTAL}

The rats were albino males obtained commercially. In the experiments described fifty-four rats were used, but not all the determinations were repeated on all the animals.

The experiments were done over a period of 3 years. The first eighteen rats are referred to as those of Expt I. Thereafter two groups of twelve rats were used to amplify the results of the first experiment; these are referred to as Expts 2 and 3 . Additional rats were used for subsidiary experiments, which are described in the text.

The rats were fed on a commercial stock diet until they had reached a weight of about $100 \mathrm{~g}$. Control rats were continued on this diet, and injected with labelled lysine when weighing about $15 \circ \mathrm{g}$. For producing protein depletion a low-protein diet was used with the following composition per $100 \mathrm{~g}$ : casein 6; salt mixture 2; dried powdered yeast 2 ; sucrose 70 ; lard 20 . This diet was given for $5-8$ weeks before 
the injection of labelled lysine. The rats survived on this low-protein diet for considerable periods, but did not grow. The loss in body-weight varied from one group of rats to another. Most rats after 6 weeks on this diet weighed between 80 and $100 \mathrm{~g}$.

With a few exceptions, which will be explained, all rats were killed 3 days after the injection of labelled lysine. During this 3 -day period some of the rats on both dietscontrol and low-protein-were put on a protein-free diet. This had the same composition as the low-protein diet, except that sucrose was substituted for casein. The purpose was an attempt to separate the effect of acute deprivation of protein from that of chronic depletion lasting several weeks. According to their dietary treatment the animals can therefore be divided into four groups.

Injection of labelled lysine. $\mathrm{L}-\left[\mathrm{U}-{ }^{14} \mathrm{C}\right]$ lysine was obtained from the Radiochemical Centre, Amersham. It was dissolved in water containing carrier L-lysine dihydrochloride, $2 \mathrm{mg} / \mathrm{ml}$, and injected intraperitoneally in a dose of approximately $10 \mu \mathrm{c} /$ I00 $\mathrm{g}$ body-weight. The exact dose given was measured by weighing the syringe.

Treatment of tissues. The rats were anaesthetized with diethyl ether, blood was taken from the heart and they were then killed. Liver, kidneys and brain were removed and weighed separately. Samples of liver, muscle and skin were taken for the measurements described below. The remaining viscera, including heart, lungs and genital organs, were pooled and weighed together. The skin was stripped off, and the carcass kept in the deep freeze. The frozen carcass was divided as accurately as possible into two halves along the midline, and each half was weighed separately. One half was used for measurement of total $\mathrm{N}$ and radioactivity, the other for measurement of total muscle mass.

Weighed samples of skin and muscle (200-500 $\mathrm{mg}$ ) were taken for fractionation of proteins, and stored in Polythene tubes in the deep freeze.

For measurement of the specific activity (sp. ac.) of free lysine, 2-3 g samples of muscle and liver were ground up with 10 volumes of $1 \%(w / v)$ picric acid; these samples were taken as soon as possible after the death of the animal. Serum was treated with 5 volumes of picric acid. The supernatant liquids were separated by centrifuging. With muscle, a part of the precipitated protein was hydrolysed by refluxing overnight in $6 \mathrm{~N}-\mathrm{HCl}$ for measurements of the sp. ac. of protein-bound lysine.

When measurements were being made of total muscle mass, an additional muscle sample, weighing about $200 \mathrm{mg}$, was taken for estimation of creatinine content.

Total $N$ and radioactivity. The organs or samples of organs were treated with $0.5 \mathrm{~N}-\mathrm{NaOH}$, about $3 \mathrm{ml} / \mathrm{g}$, with heat if necessary, until all the material was dissolved. The volumes of the solutions were recorded and portions taken for measurement of $\mathrm{N}$ and of radioactivity. This treatment gives a figure for the sp. ac. (counts/ min per $\mathrm{mg} \mathrm{N}$ ) of the mixed proteins of the tissue. This is an approximate measurement, which is open to two sources of error. The first is contamination by labelled free amino acid. For the purposes of our experiments this contamination is not likely to be significant since our results show that, 3 days after the injection of labelled lysine, free lysine accounts for less than $3 \%$ of the total radioactivity recovered from the body. The second source of error is contamination by plasma proteins. This would 
particularly affect the skin, in which the proteins are not highly labelled, but which has a large extracellular compartment, and also contains some albumin that is in fairly rapid equilibrium with that of the plasma (Humphrey, Neuberger \& Perkins, 1957). To test the extent of this error, samples of liver, muscle and skin from six rats were shaken for $10 \mathrm{~min}$ in ice-cold $0.9 \%(\mathrm{w} / \mathrm{v}) \mathrm{NaCl}$ to wash out trapped plasma proteins. The protein in the saline extract was then precipitated with trichloroacetic acid, counted and its $\mathrm{N}$ content measured. The total counts in the saline extract, as a percentage of the counts in the remaining tissue, were: liver $\mathrm{I} \cdot 05$, muscle $2 \cdot 8 \mathrm{r}$, skin 3.9 . Therefore this soluble protein, although much more highly labelled than the bulk of muscle or skin protein, does not account for more than a small fraction of the total tissue radioactivity.

Total muscle mass. Half of each carcass was placed in a conical flask with about $150 \mathrm{ml} 1 \%$ picric acid and autoclaved in a pressure cooker for $75 \mathrm{~min}$. A sample of muscle was treated in the same way. After autoclaving, the picric acid extracts were separated, and the tissue was extracted again for $\mathrm{I} h$ with a further volume of picric acid. 'The combined extracts were made up to a known volume, and their creatine contents were measured, as creatinine, by the method of Bonsnes \& Taussky (1945); this allowed application of the equation:

$$
\text { Muscle mass } / \text { Ioo g carcass }=\frac{\text { creatinine } / \mathrm{roog} \text { carcass }}{\text { creatinine/g muscle }} \text {. }
$$

The method depends upon two assumptions: that there is no creatine or creatinine in the carcass except in muscle; and that the content of creatine + creatinine of the muscle sample measured is representative of the muscle mass as a whole. In man the muscle mass was found by Wilmer ( 1940 ) to be about $40 \%$ of body-weight. The results in Table I show that the calculated muscle mass ranged from 34 to $44 \%$ of the bodyweight in the different groups of rats, being lowest in the control group, which was the best nourished and probably had the most body fat.

Total $\mathrm{N}$ and radioactivity were measured in the other half carcass, and in another muscle sample. From these values, and from that for total muscle mass, it is possible to calculate in the carcass the proportions of $\mathrm{N}$ and of radioactivity derived from muscle. The remaining $\mathrm{N}$ and activity in the carcass, that are not derived from muscle, are referred to as 'residue' $\mathrm{N}$ and activity. This residue contained $7-20 \%$ of total body $\mathrm{N}$ in individual rats. Anatomically, it presumably consisted mainly of connective tissue, including that of the skeleton, but it must also have contained a considerable proportion of cellular material, e.g. bone marrow, lymphoid tissue and some residual blood. As Table 5 shows, the calculated sp. ac. of this residue was consistently higher than that of either muscle or skin, and approached that of the viscera. The sp. ac. is too high to be accounted for simply on the basis of trapped plasma protein or protein of interstitial fluid.

Fractionation of muscle. The procedure was essentially that of Dickerson (1960). Samples (150-200 mg) of muscle were homogenized in $3 \mathrm{ml}$ portions of ice-cold dilute salt solution. The residue was then extracted three times with $0^{\circ} \mathrm{I} \mathrm{N}-\mathrm{NaOH}$ at $0^{\circ}$. These extracts were too dilute for direct measurements of radioactivity to be made. 
The protein was therefore precipitated with $10 \%(\mathrm{w} / \mathrm{v})$ trichloroacetic acid, and the precipitate dissolved in a small volume of $0.5 \mathrm{~N}-\mathrm{NaOH}$ with warming. Samples of this solution were taken for measurement of $\mathrm{N}$ and radioactivity.

Fractionation of skin. About $500 \mathrm{mg}$ of skin were soaked for $\frac{1}{2}-\mathrm{I}$ h at room temperature in $5 \mathrm{ml} 10 \%(\mathrm{w} / \mathrm{v}) \mathrm{Na}_{2} \mathrm{~S}$ to remove most of the hair. The liquid was poured off and the remaining tissue shaken three times with a small volume of water. These washings were added to the $\mathrm{Na}_{2} \mathrm{~S}$ extract to form the 'hair' fraction. The residue stood overnight in the refrigerator in $3 \mathrm{ml} 0.1 \mathrm{~N}-\mathrm{NaOH}$. The supernatant liquid was poured off, and the residue extracted twice more with ice-cold $0 . \mathrm{I} \mathrm{N}-\mathrm{NaOH}$. In one experiment this extraction was done by homogenizing in a high-speed micro-blender. In another group of rats a gentler method was used, the tissue being shaken for to min in a mechanical shaker; the gentler treatment extracted rather less $\mathrm{N}$. The $\mathrm{NaOH}$ extracts were combined and called $\mathrm{F}_{\mathrm{I}}$. The insoluble material left was dissolved by heating in a small volume of $0.5 \mathrm{~N}-\mathrm{NaOH}$, to give the fraction called $\mathrm{F}_{2}$. Samples of these three fractions were taken for measurement of $\mathrm{N}$ content and radioactivity. In some rats another sample of skin was taken, and hydrolysed in $6 \mathrm{~N}-\mathrm{HCl}$. Hydroxyproline was estimated in the hydrolysate by the method of Leach (1960).

Specific activity of lysine. The picric acid was removed from the extracts of liver, muscle and serum by passing them through columns of Deacidite FF resin (Permutit Co. Ltd) and the amino acids were collected on Dowex 50 columns (Dow Chemical Co., Midland, Michigan, USA). After thorough washing of the columns with water, the amino acids were eluted with $7 \%$ ammonia solution, and the eluate was evaporated to dryness in a desiccator over conc. $\mathrm{H}_{2} \mathrm{SO}_{4}$ and $\mathrm{P}_{2} \mathrm{O}_{5}$. The dry residue was taken up in $25^{-100} \mu \mathrm{l}$ of $0.1 \mathrm{~N}$-acetate buffer, $\mathrm{pH} 5^{2}$. The lysine content was measured by reacting with L-lysine decarboxylase (Sigma Chemical Co.) in the Cartesian diver microrespirometer. In the diver $0.5 \mu \mathrm{l}$ of the extract was mixed with $2 \mu \mathrm{l}$ of enzyme suspension ( $20 \mathrm{mg} / \mathrm{ml}$ in acetate buffer). The reaction was complete within an hour, and quantitative. For measurement of radioactivity 25 or $50 \mu 1$ of extract were placed in the outer chamber of no. 2 Conway units, together with $200 \mu \mathrm{l}$ of enzyme suspension. A planchette containing $100 \mu \mathrm{l}$ of $0.5 \mathrm{~N}-\mathrm{NaOH}$ was placed on the centre well to trap the $\mathrm{CO}_{2}$ evolved. The reaction was allowed to proceed for $3 \mathrm{~h}$ after sealing and mixing. The planchettes were then dried and the radioactivity was determined. This method has been used previously by Barry (1952) and by Penn, Mandeles \& Anker (1957).

For measurement of the sp. ac. of protein-bound lysine in muscle, part of the picric acid precipitate was refluxed with $6 \mathrm{~N}-\mathrm{HCl}$ overnight (about $50 \mathrm{ml} \mathrm{HCl}$ to I $\mathrm{g}$ muscle). The acid was evaporated off in vacuo, the residue taken up in water, filtered and passed through columns in the same way as the picric acid supernatant fractions. The dried extracts were then treated in the same way as the free lysine extracts. A portion of the extract was also plated directly on planchettes and the radioactivity counted. Theoretically, if all the radioactivity is in lysine the direct counts per unit volume should be six times the counts obtained from $\mathrm{CO}_{2}$ liberated in the Conway units. If the ratio of $6 \times$ counts in $\mathrm{CO}_{2}$ to direct counts is less than $\mathrm{I}$, either there must be radioactive substances present which are not L-lysine, or the decarboxylation reaction must be 
incomplete. The mean ratio in twenty-nine consecutive comparisons was 0.99 . In view of this, in the later experiments the free amino acid extracts, in which the radioactivity tends to be low, were counted directly, without decarboxylation in Conway units.

Radioactivity. This was measured in a windowless gas-flow counter (Garrow \& Piper, 1955). The samples were plated on mumetal planchettes $\mathrm{I} \cdot 5 \mathrm{~cm}$ in diameter. Even spreading was ensured by discs of lens paper stuck to the planchettes with $25 \mu 1$ of $5 \%(\mathrm{w} / \mathrm{v})$ sucrose solution. The sample volume was usually $200 \mu \mathrm{l}$. The planchettes were dried under a lamp and weighed. All counts were corrected for self-absorption by an empirically determined curve.

Nitrogen. $\mathrm{N}$ was measured by digestion, followed either by micro-Kjeldahl distillation and titration, or by Nesslerization.

Amino nitrogen. This was determined colorimetrically with ninhydrin by the method of Jagenburg (1959).

Chloride. The partition of lysine and of amino $\mathrm{N}$ between intra- and extra-cellular water of liver and muscle was calculated from the chloride content of these tissues and of serum. Chloride was measured in the picric acid supernatant fractions by iodometric titration after the addition of silver iodate (Sendroy, 1937). The picric acid does not interfere with the reaction, except that the starch indicator is green instead of blue.

\section{RESULTS}

\section{Distribution of body $N$}

Table I shows in the four groups of rats the proportion of total body $\mathrm{N}$ contributed by the various tissues analysed. The differences in pattern are not very striking. In acute depletion (stock diet followed by protein-free diet) the proportion of total body $\mathrm{N}$ in liver, viscera and residue was reduced, in muscle it was increased. In more chronic depletion (low-protein diet) these changes were not so great and in liver the proportion of $\mathrm{N}$ was increased. Muscle $\mathrm{N}$ remained a fairly constant proportion of total body $\mathrm{N}$.

It is also illuminating to consider the absolute amounts of $\mathrm{N}$, as well as the changes in pattern of distribution. Table 2 shows the absolute $\mathrm{N}$ content of the various tissues, calculated as the mean for each group, and expressed as a percentage of the amount in the control group. Table 3 shows the contribution made by each tissue to the total $\mathrm{N}$ deficit in the depleted animals. It is more accurate to refer to the differences as deficits rather than losses, because in these young rats they represented lack of growth as much as actual loss. In liver, viscera and carcass residue a protein-free diet for only 3 days produced a substantial $\mathbf{N}$ deficit. With more chronic depletion there was not much further 'loss' from the liver, so that the proportion of the total deficit that is contributed by the liver fell as the deficiency progressed. This is in agreement with the well-known findings of Addis, Poo \& Lew (1936), and of Widdowson \& McCance (1956).

The carcass residue responded according to the same pattern, but to an even greater degree. In acute depletion $50 \%$ of the $\mathrm{N}$ deficit was contributed by this fraction. This 
Vol. 20

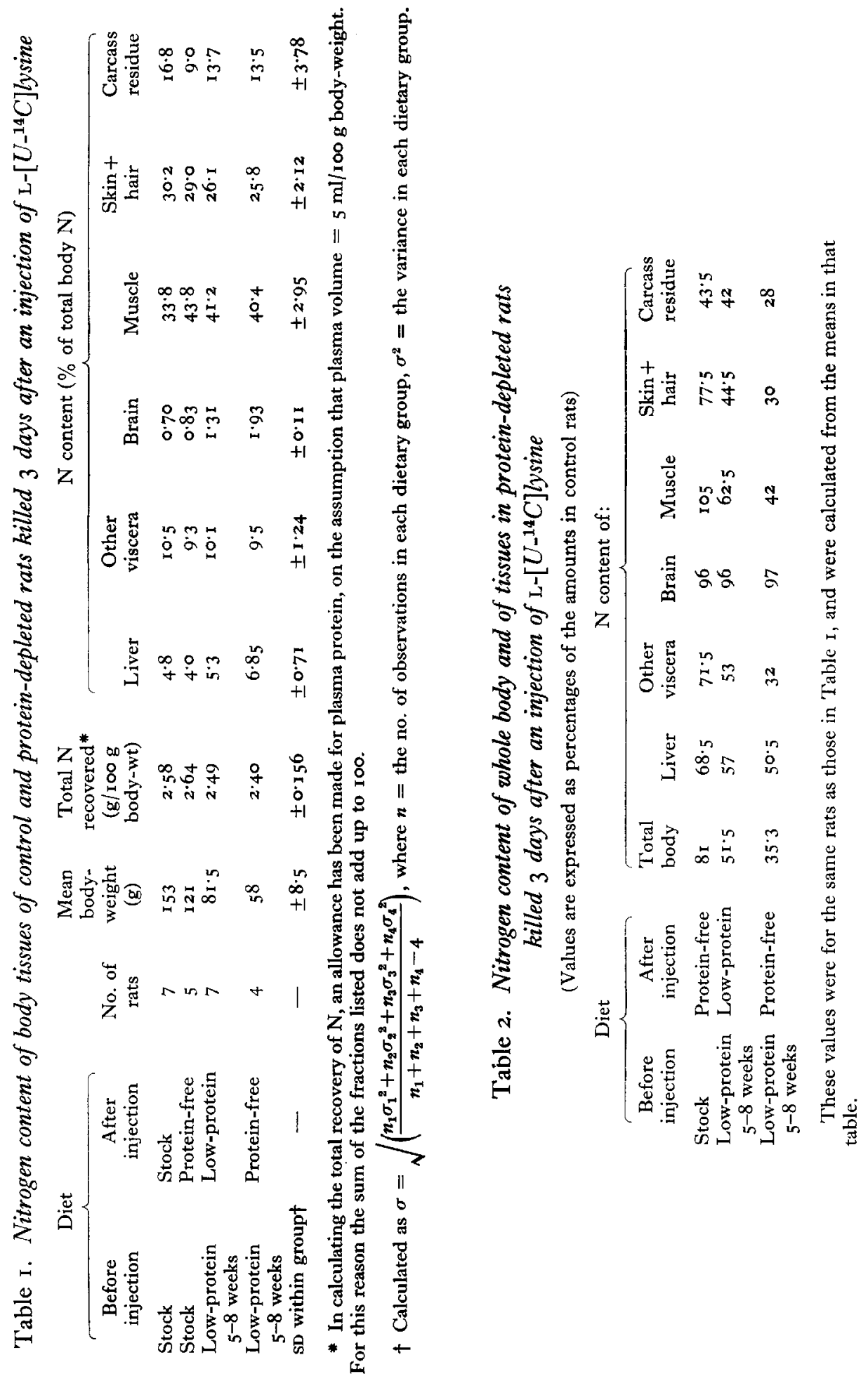


finding was unexpected, and cannot easily be interpreted, since the residue was a mixture of many tissues. As will be seen later, the measurements of sp. ac. suggest that the residue must have contained some components with a high rate of turnover. These probably included lymphoid tissue, bone marrow and soluble collagen.

The total $\mathrm{N}$ content of brain was almost the same in all groups. This constancy under different dietary conditions might for certain purposes provide a useful basis of reference.

Table 3. Contribution of different tissues to the total nitrogen deficit in proteindepleted rats killed 3 days after an injection of $\mathrm{L}-\left[U_{-}{ }^{14} C\right]$ lysine

\begin{tabular}{|c|c|c|c|c|c|c|c|c|}
\hline \multicolumn{2}{|c|}{ Diet } & \multirow{2}{*}{$\begin{array}{l}\text { Mean } \\
\text { total } \\
\mathrm{N} \text { of } \\
\text { whole } \\
\text { body } \\
\text { (mg) }\end{array}$} & \multirow[b]{2}{*}{$\begin{array}{l}\text { Deficit } \\
\text { (mg) }\end{array}$} & \multicolumn{5}{|c|}{$\%$ of deficit contributed by: } \\
\hline $\begin{array}{l}\text { Before } \\
\text { injection }\end{array}$ & $\begin{array}{c}\text { After } \\
\text { injection }\end{array}$ & & & Liver & $\begin{array}{l}\text { Other } \\
\text { viscera }\end{array}$ & Muscle & $\begin{array}{c}\text { Skin }+ \\
\text { hair }\end{array}$ & $\begin{array}{l}\text { Carcass } \\
\text { residue }\end{array}$ \\
\hline Stock & Stock & $395^{\circ}$ & - & - & - & - & - & - \\
\hline Stock & Protein-free & 3190 & 760 & $7 \cdot 8$ & 15.7 & $-8 \cdot 5$ & 35.0 & $49 \cdot 3$ \\
\hline $\begin{array}{l}\text { Low-protein } \\
5^{-8} \text { weeks }\end{array}$ & Low-protein & 2030 & 1920 & $4 \cdot 2$ & 10.3 & $25 \cdot 9$ & $34 \cdot 5$ & $20 \cdot 0$ \\
\hline $\begin{array}{l}\text { Low-protein } \\
5-8 \text { weeks }\end{array}$ & Protein-free & I 390 & 2560 & $3 \cdot 6$ & $\mathrm{II} \cdot \mathbf{I}$ & $30 \cdot 2$ & $32 \cdot 5$ & $18 \cdot 6$ \\
\hline
\end{tabular}

These values were for the same rats as those in Table $\mathbf{I}$, and were calculated from the means in that table.

The deficit is the difference in total body $\mathrm{N}$ between the experimental and the control groups.

Muscle showed no loss of $\mathrm{N}$ in acute depletion; the small increase in absolute $\mathrm{N}$ content is within experimental error. In more prolonged depletion there was a large 'loss' of muscle $\mathrm{N}$, and the contribution of muscle to the total deficit progressively increased. The skin and hair, unlike muscle, showed a substantial 'loss' on acute depletion; in more chronic deficiency the skin continued to lose $\mathrm{N}$ at about the same rate as the body as a whole, so that its contribution to the total $\mathrm{N}$ deficit remained constant at about $35 \%$. In both groups of animals on the low-protein diet the skin contributed a larger proportion of the deficit than any of the other tissues. This is in agreement with the findings of Cabak, Dickerson \& Widdowson (1963) that in the rat skin appears to be an important storage organ for $\mathrm{N}$.

These results emphasize that in the malnourished animal the pattern of the component tissues of the body is constantly changing, according to the duration and degree of the deficiency (Waterlow, 1962).

\section{Distribution of radioactivity}

Table 4 shows the distribution of counts in various organs expressed as a percentage of the total counts recovered. The overall recovery was much the same in all the animals, and there was no evidence that the depleted rats economized lysine by reduced oxidation. In fact, it is remarkable that the recoveries should have been so high even in the control animals. This confirms the observation of Hagan \& Scow (1957) that muscle is resistant to depletion during the initial stages of fasting. 
Vol. 20

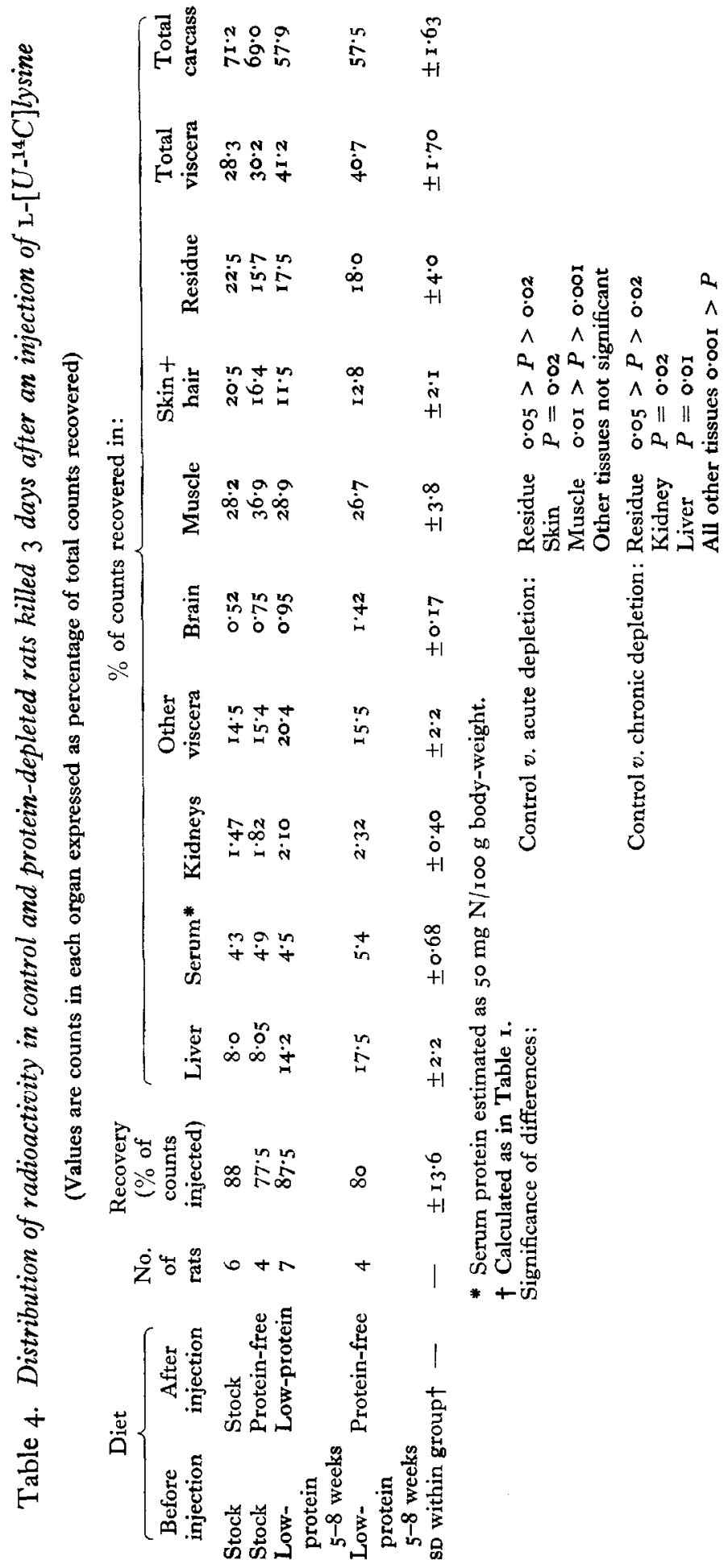




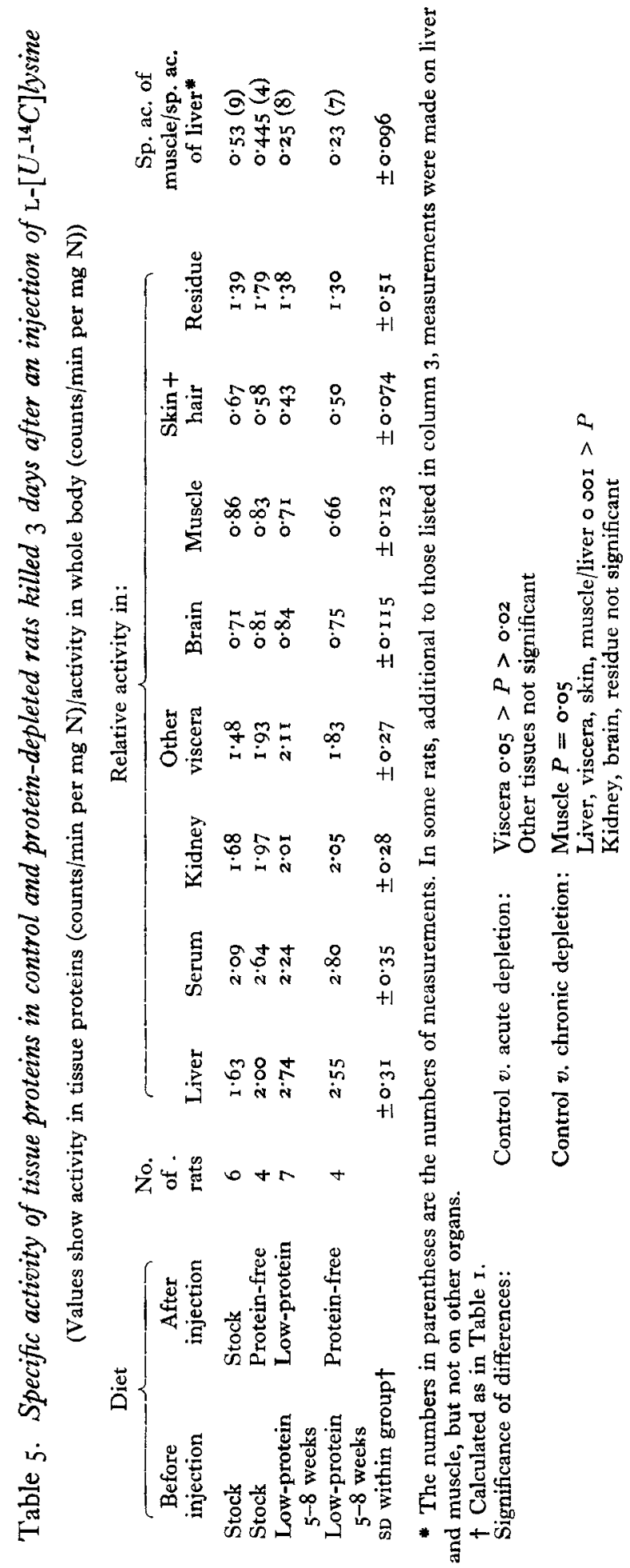


The results in Table 4 confirm the previous finding (Waterlow, 1959) that, 3 days after the injection of a labelled amino acid, rats which have been on a low-protein diet retain relatively more radioactivity in the internal organs and less in the carcass than control rats. Thus in both groups receiving the low-protein diet the ratio of total counts in the carcass to total counts in the viscera was 1.4 , compared with 2.5 in the control group.

The liver was mainly responsible for the increased retention of isotope in the viscera. The total activity in the serum was much the same in all the groups. These values have been calculated on the assumption that total body serum protein $\mathrm{N}=5^{\circ}$ $\mathrm{mg} / \mathrm{I} 00 \mathrm{~g}$ body-weight. This assumption takes no account of the fact that in the depleted animals serum protein concentrations were reduced. The values in the table for these groups are therefore overestimates. The skin and the residue fractions were mainly responsible for the reduced uptake in the carcass. The proportion retained in muscle was the same in the depleted and in the control animals.

Table 5 shows the sp. ac. (counts/min per $\mathrm{mg} \mathrm{N}$ ) in various organs compared with the average sp. ac. of the total body protein. This method of expression shows the radioactivity in each organ after allowing for the altered distribution of $\mathrm{N}$. In the depleted animals the relative sp. ac. tended to be increased in liver, serum and internal organs; there was no consistent change in brain and in carcass residue; the sp. ac. was moderately reduced in muscle and in skin. The carcass residue in all groups had a rather high sp. ac., intermediate between that of muscle and viscera. It is evident that in the control animals the sp. ac. was more uniform, possibly suggesting a more rapid approach to equilibrium between the different body proteins.

\section{Fractionation of muscle and skin}

One of the possible causes for the reduced uptake of radioactivity by muscle and skin in the depleted animals is that in these tissues there might have been a preferential loss of proteins with a relatively high rate of replacement, leaving behind those which are replaced more slowly. To test this suggestion, a crude chemical fractionation was made of muscle and of skin in a small number of rats, including some which had not been injected with labelled amino acids.

Muscle. In our hands the fractionation of muscle proteins in samples of about 200 $\mathrm{mg}$ has given rather variable results. Table 6 shows that protein depletion had little effect on the distribution of $\mathrm{N}$ between the two main fractions-sarcoplasmic and fibrillar. The differences between the groups were not significant. The value of $0 \cdot 3$ for the ratio sarcoplasmic $\mathrm{N}$ : fibrillar $\mathrm{N}$ in the control group was almost the same as the value of 0.29 obtained by Cabak et al. (1963) for normal rats. From the figures given by these workers it appears that in depleted rats the ratio tends to decrease, although the differences are probably too small to be significant. Hagan \& Scow (1957) found that in rats fasted for 3 days the water-soluble $\mathrm{N}$ (which includes our sarcoplasmic $\mathrm{N}$ ) was more labile than the myosin $\mathrm{N}$. In the experiments now presented in which the rats were not fasted, but deprived only of protein, the change tended to be in the opposite direction.

In control rats the sp. ac. of the two protein fractions was the same, within the 

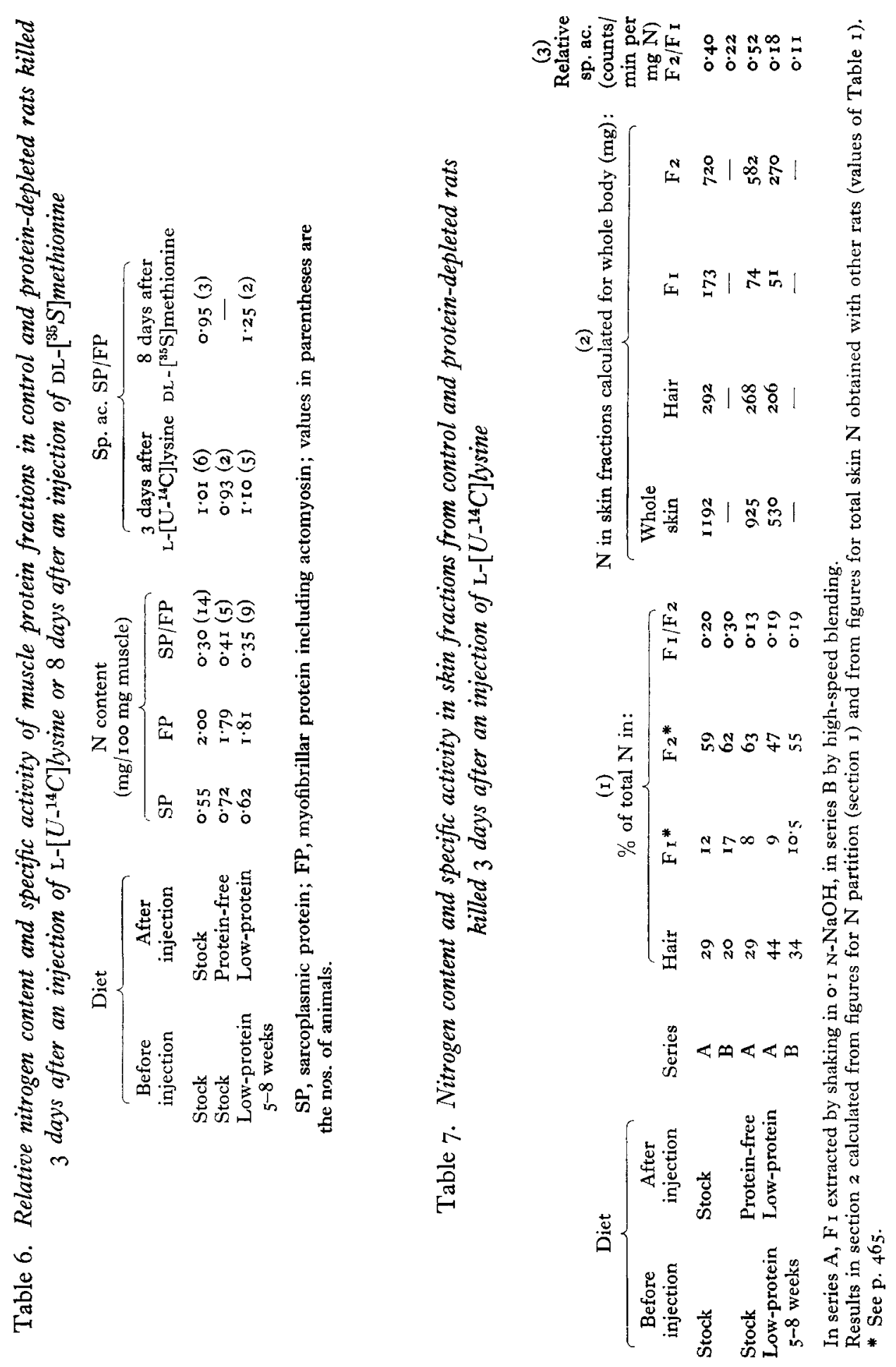
limits of experimental error, both at 3 days and at 8 days after the injection of labelled amino acid. This finding was rather surprising. It had been expected that the sarcoplasmic fraction would be replaced more rapidly. Bidinost (I95I) found that in rats fed on a $15 \%$ casein diet, and given $\left[{ }^{15} \mathrm{~N}\right]$ glycine, the myosin fraction had a slightly lower sp. ac. than the whole muscle.

There was a tendency for the sarcoplasmic fraction to have a slightly higher sp. ac. in the rats chronically deprived of protein, but the increase was not significant in this small number of animals. Mendes (1959) using [ $\left.{ }^{35} \mathrm{~S}\right]$ methionine was also unable to demonstrate any differential effect of different diets on the sp. ac. of different muscle fractions. The results suggest, in general, that the reduced uptake of radioactivity by muscle in the depleted animals cannot be explained by an alteration in the proportions of the two main protein fractions.

Skin. The partition of $\mathrm{N}$ between the three fractions of skin is shown in Table 7 . In series $A$ the cellular protein was extracted by shaking the tissue in dilute alkali, whereas in series $B$ the extraction was done in a high-speed blender. In the depleted animals the $\mathrm{N}$ content of the cellular fraction $\mathrm{F}_{\mathrm{I}}$ tended to be reduced compared with that of the fibrous fraction F 2. The difference appeared with the more violent method of extraction.

The changes in the absolute amount of $\mathrm{N}$ in the different fractions are shown when the values for the distribution of $\mathrm{N}$ are multiplied by those obtained earlier for the total amount of skin $\mathrm{N}$ in the whole animal. The results of this calculation are shown in the second part of 'Table 7 . It appears that hair $\mathrm{N}$ content was relatively well preserved. In acute deprivation (normal diet followed by protein-free diet) a large loss of $\mathrm{N}$ was found in the fraction $\mathrm{F}_{\mathrm{I}}$, which probably consisted mainly of cellular protein. The total $\mathrm{N}$ of this fraction was $43 \%$ of that in the control rats, whereas the $\mathrm{N}$ content of fraction $\mathrm{F} 2$, which was mainly fibrous, was well preserved, amounting to $8 \mathrm{I} \%$ of that in the controls. In chronic depletion (low-protein diet throughout) the $\mathrm{N}$ content of $\mathrm{F} 2$ was more severely reduced, amounting to only $37 \%$ of that in the controls.

In series B, hydroxyproline was measured in hydrolysates of samples of the whole skin, and the collagen content was calculated. The percentage of the $\mathrm{N}$ in $\mathrm{F} 2$ that could be accounted for as collagen was 64 in control rats and 94 in depleted rats. These results suggest that fraction $\mathrm{F}_{2}$ contained a component which was not collagen, and which tended to be labile. This alone cannot account for the large reduction in the total $\mathrm{N}$ content of fraction $\mathrm{F} 2$ (Table 7 , section 2 ). There must also have been a substantial loss of collagen; this is in agreement with the findings of Cabak et al. (1963). In the chronically depleted animals the sp. ac. of fraction $\mathrm{F}_{2}$ was greatly reduced compared with that of fraction $\mathrm{F}_{\mathrm{I}}$.

\section{The concentration of free lysine in blood and tissues}

The values found for the free lysine content of liver, muscle and serum are shown in Table 8 . The results of the three experiments are reported separately, because they show some variation from one set of rats to another.

In liver in Expt $\mathbf{I}$ the difference between the control group and that receiving the low-protein diet throughout was just significant $(P=0.05)$. In Expt 2 the control 


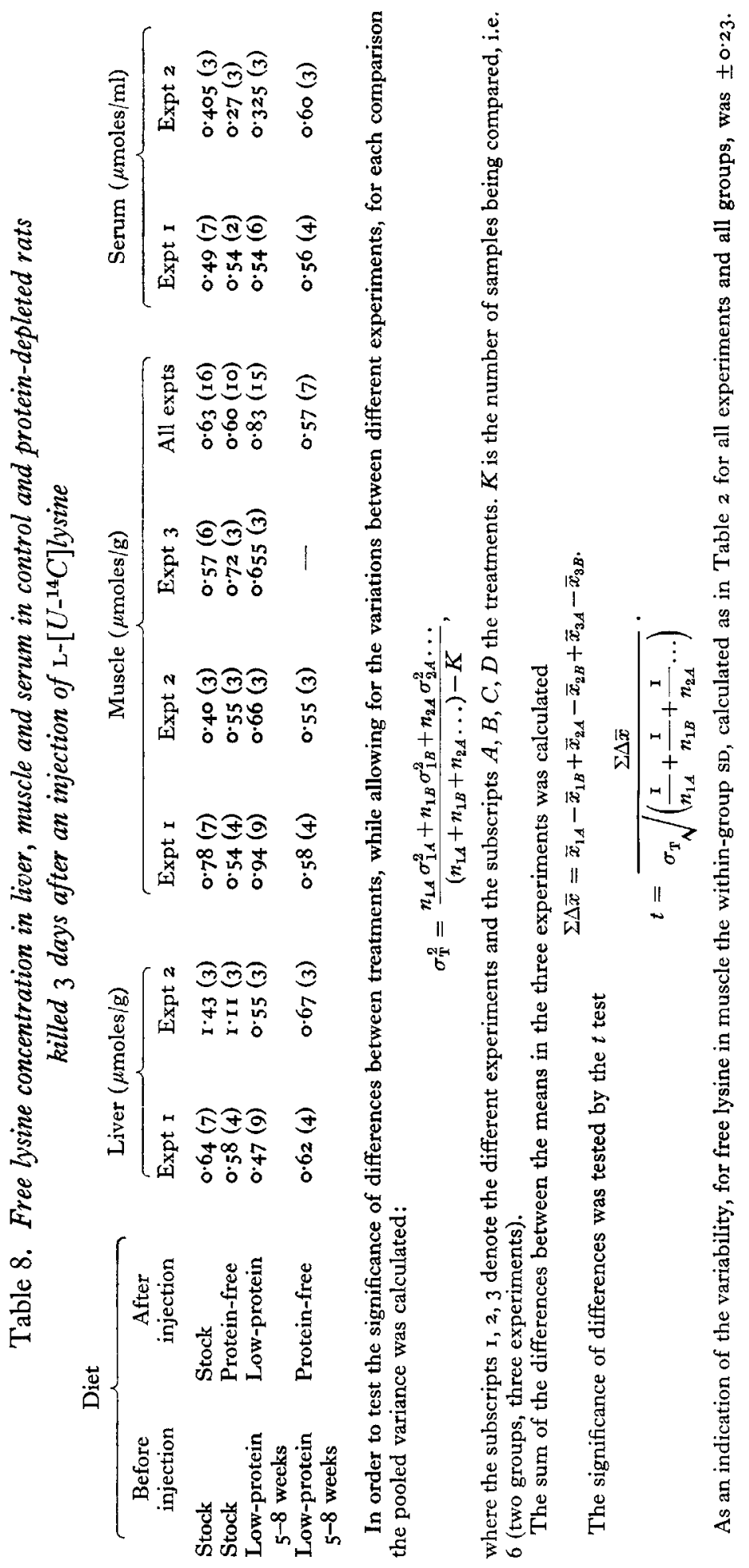


animals had much higher levels of free lysine than the depleted rats. In muscle and serum there was no significant difference in any of the experiments between the results in the different dietary groups.

Our average values for the amounts of free lysine in liver, muscle and serum agree well with those of Thompson, Schurr, Henderson \& Elvehjem (1950). However, much higher levels were found by Allison, Wannemacher \& Banks (1963) and by R. W. Wannemacher (personal communication) in muscle of young rats weighing about $100 \mathrm{~g}$, such as those used in these experiments. In one experiment, which was not part of the series reported here, we also found much larger amounts of free lysine in muscle, and a marked fall when a low-protein diet was given. In five rats with a mean body-weight of $116 \mathrm{~g}$, fed on a $16 \%$ casein diet, the mean lysine content of muscle was $3.21 \mu$ moles $/ g$. In five rats fed on a $6 \%$ casein diet for $10-14$ days, and with an average weight of $9^{8} \mathrm{~g}$, the average muscle lysine content was $\mathrm{I} \cdot 43 \mu$ moles $/ \mathrm{g}$. In later experiments (Expts 2 and 3 , Table 8) we have not found these high values nor the difference between the dietary groups. We are unable to explain these variations between batches of animals.

Table 9. Total amino nitrogen in liver, muscle and serum in control and proteindepleted rats killed 3 days after an injection of $\mathrm{L}-\left[U_{-}{ }^{14} C\right]$ lysine

\begin{tabular}{|c|c|c|c|c|c|}
\hline \multicolumn{2}{|c|}{ Diet } & \multirow{2}{*}{$\begin{array}{l}\text { No. } \\
\text { of } \\
\text { rats }\end{array}$} & \multicolumn{3}{|c|}{ Total amino $\mathrm{N}$} \\
\hline $\begin{array}{l}\text { Before } \\
\text { injection }\end{array}$ & $\begin{array}{c}\text { After } \\
\text { injection }\end{array}$ & & $\begin{array}{c}\text { Liver } \\
(\mu \text { moles } / \mathrm{g})\end{array}$ & $\begin{array}{c}\text { Muscle } \\
(\mu \text { moles } / \mathrm{g})\end{array}$ & $\underset{(\mu \text { moles } / \mathrm{ml})}{\text { Serum }}$ \\
\hline Stock & Stock & 7 & I 8.4 & 17.5 & $4 \cdot 2$ \\
\hline Stock & Protein-free & 4 & $2 I \cdot I$ & I $3 \cdot 4$ & 3.65 \\
\hline $\begin{array}{l}\text { Low-protein } \\
5-8 \text { weeks }\end{array}$ & Low-protein & 9 & $20 \cdot 0$ & $22 \cdot 0$ & 4.9 \\
\hline $\begin{array}{c}\text { Low-protein } \\
5-8 \text { weeks }\end{array}$ & Protein-free & 4 & $2 \tau \cdot 0$ & $21 \cdot 0$ & $4 \cdot 35$ \\
\hline
\end{tabular}

Table 10. Concentration ratio of free lysine and total amino $N$ in liver and muscle in control and protein-depleted rats killed 3 days after an injection of $\mathrm{L}-\left[U-{ }^{14} C\right]$ lysine

(Values show concentration $(\mu \mathrm{moles} / \mathrm{ml})$ in intracellular water/concentration $(\mu \mathrm{moles} / \mathrm{ml})$ in extracellular water)

\begin{tabular}{|c|c|c|c|c|c|c|}
\hline \multicolumn{2}{|c|}{ Diet } & \multirow{3}{*}{$\begin{array}{c}\text { No. } \\
\text { of } \\
\text { rats }\end{array}$} & \multirow{2}{*}{\multicolumn{2}{|c|}{ Free lysine }} & \multirow{2}{*}{\multicolumn{2}{|c|}{ Total amino $\mathrm{N}$}} \\
\hline & & & & & & \\
\hline injection & injection & & Liver & Muscle & Liver & Muscle \\
\hline Stock & Stock & 4 & $2 \cdot 36$ & $2 \cdot 15$ & II 3 & $6 \cdot 5$ \\
\hline Stock & Protein-free & 2 & $2 \cdot 17$ & $x \cdot 67$ & $15^{\circ} 0$ & $5 \cdot 9$ \\
\hline $\begin{array}{l}\text { Low-protein } \\
5-8 \text { weeks }\end{array}$ & Low-protein & 3 & $I \cdot 49$ & $I \cdot 96$ & $15 \cdot 2$ & $7 \cdot 4$ \\
\hline $\begin{array}{l}\text { Low-protein } \\
5-8 \text { weeks }\end{array}$ & Protein-free & 4 & $3 \cdot 4 \mathrm{I}$ & $I \cdot 40$ & $2 I \cdot 2$ & 10.0 \\
\hline
\end{tabular}

In six rats an attempt was made to estimate the total amount of free lysine in the whole body by summing the results of separate measurements on liver, viscera, carcass (including muscle) and skin. No allowance was made for blood. The results were: in three rats fed on a normal diet, 70, 55, 79 (mean $68 \mu$ moles/roo g); in three rats fed on a protein-free diet for 3 days, $76,79,65$ (mean $73 \mu$ moles/roo g). 
In the rats of Expt I, measurements were also made of the total amino $\mathrm{N}$ of liver, muscle and serum. The results are shown in Table 9. The total amino $\mathrm{N}$ of liver was rather constant. In muscle and serum it was reduced in the acutely depleted animals. In muscle the reduction was highly significant compared with all the other three groups. In the chronically depleted rats, on the other hand, the amino $\mathrm{N}$ of muscle was increased: the difference between the control group and that receiving a lowprotein diet throughout was significant $(P<0.001)$.

In some of the rats of Expt $x$ the chloride content of the tissues was measured, and on the assumption that all chloride is extracellular a calculation was made of the ratio of the concentrations of free lysine and total amino $\mathrm{N}$ in intra- and extra-cellular water. The results are shown in Table I0. Because of the indirect nature of the calculation, and the small number of animals, it is doubtful if the differences between the groups in the concentration ratio of free lysine have any significance. The results for total amino $\mathrm{N}$ in the normal rat are in good agreement with those of Christensen, Streicher \& Elbinger (1948). The findings in the groups fed on a low-protein diet suggest that protein deprivation tended to cause an increase in the concentration ratio in both liver and muscle. This cannot, of course, be taken as evidence of a normal transport mechanism, as the intracellular concentration depends not only on the rate of transport into the cell, but also on the rates of amino acid uptake by protein synthesis, and of liberation by protein katabolism.

The concentration ratio for total amino $\mathrm{N}$ was much higher than that for lysine. The intracellular concentrations of the individual amino acids appear to be very different (Thompson et al. 1950), and in general the non-essential amino acids seem to be more concentrated than the essential. Manchester \& Wool $(1963)$ found that in the perfused rat heart lysine had the lowest concentration ratio of all the amino acids tested.

The picture that emerges from our results is in agreement with that drawn by Roberts $\&$ Simonsen (1962). Even severe dietary protein restriction causes little change in the size of the free amino acid pool, and such changes as occur may be in either direction. This is perhaps not surprising, since the total amount of free lysine in the body at any moment is only about $5 \%$ of that liberated by turnover in $24 \mathrm{~h}$ (Stephen \& Waterlow, 1965).

\section{Specific activity of free lysine}

The sp. ac. of free lysine in serum, liver and muscle 3 days after the injection of the labelled amino acid is shown in Table Ir. These values are corrected for dose and body-weight. The variability was rather large, but in all groups the sp. ac. in serum tended to be a little higher than in liver or muscle.

Table I I also shows the ratio of the sp. ac. of free lysine of muscle to that of liver. The ratio was lower in the protein-depleted animals. The difference between the control group and that receiving the low-protein diet throughout was significant $(0.05>P>0.01)$, as the first part of the table shows, seemingly because of the higher sp. ac. in liver rather than a lower one in muscle.

In general it seems that 3 days after the injection the sp. ac. of free lysine in the three tissues examined was fairly uniform. This is further illustrated by the results in Table 
I2. In the experiment illustrated there, six rats were divided into two groups of three. One group was put on a protein-free diet 3 days before the injection of labelled lysine. One animal of each group was killed at 6,24 and $48 \mathrm{~h}$ after the injection, and the sp. ac. of free lysine measured in six different tissues. By $48 \mathrm{~h}$ there seemed to be a fair measure of uniformity among the different tissues, except for muscle in the proteinfree group, for which the value was low.

Table I I. Specific activity of free lysine in liver, muscle and serum corrected for dose and body-weight at time of death in control and protein-depleted rats killed 3 days after an injection of $\mathrm{L}-\left[U_{-}{ }^{14} C\right]$ lysine

(Values show activity (counts $/ \mathrm{min}$ per $\mu$ mole) corrected to a dose of $10^{6}$ counts $/ \mathrm{min}$

$\begin{gathered}\text { Before } \\ \text { injection } \\ \text { Anjection } \\ \text { Stock }\end{gathered}$
$\begin{gathered}\text { Stock } \\ \text { Low-protein } \\ \text { Protein-free } \\ \text { Low-protein } \\ \text { 5-8 weeks }\end{gathered}$$\quad \begin{aligned} & \text { Low-protein } \\ & \text { Protein-free }\end{aligned}$
per $100 \mathrm{~g}$ body-weight)

Values in parentheses are the nos. of rats.

$\begin{array}{cccc}\text { Liver } & \text { Muscle } & \text { Serum } & \begin{array}{c}\text { Ratio, muscle: liver } \\ \text { (mean value } \\ \text { with its SE) }\end{array} \\ 138(7) & 166(7) & 184(6) & 1 \cdot 25 \pm 0.15 \\ 195(6) & 182(6) & 218(5) & 0.92 \pm 0.046 \\ 178(8) & 143(8) & 182(5) & 0.85 \pm 0.045 \\ 162(7) & 182(7) & 213(5) & 1 \cdot 28 \pm 0.19\end{array}$

Table 12. Specific activity (counts/min per umole) of free lysine at different time intervals after an injection of $\mathrm{L}-\left[U_{-}{ }^{14} C\right]$ lysine in rats receiving a stock diet or a protein-free diet for 3 days before the injection until death

\begin{tabular}{|c|c|c|c|c|c|c|c|c|}
\hline \multicolumn{2}{|c|}{ Diet } & \multirow{3}{*}{$\begin{array}{l}\text { Hours } \\
\text { after } \\
\text { injection }\end{array}$} & \multirow{2}{*}{\multicolumn{6}{|c|}{ Sp. ac. of free lysine in: }} \\
\hline \multirow{2}{*}{$\begin{array}{l}\text { Before } \\
\text { injection }\end{array}$} & \multirow{2}{*}{$\begin{array}{c}\text { After } \\
\text { injection }\end{array}$} & & & & & & & \\
\hline & & & Serum & Liver & Viscera & Muscle & Skin & Carcass* \\
\hline \multirow[t]{2}{*}{ Stock } & \multirow[t]{2}{*}{ Stock } & 6 & 862 & 695 & 396 & 577 & 328 & 395 \\
\hline & & $\begin{array}{l}24 \\
48\end{array}$ & $\begin{array}{l}720 \\
362\end{array}$ & $\begin{array}{l}373 \\
247\end{array}$ & $\begin{array}{l}445 \\
242\end{array}$ & $\begin{array}{l}447 \\
425\end{array}$ & $\begin{array}{l}344 \\
219\end{array}$ & $\begin{array}{l}467 \\
184\end{array}$ \\
\hline \multirow{3}{*}{$\begin{array}{l}\text { Protein-free } \\
3 \text { days }\end{array}$} & \multirow[t]{3}{*}{ Protein-free } & 6 & 785 & 537 & 400 & 577 & 316 & I 13 \\
\hline & & 24 & 463 & 578 & 410 & 285 & 290 & 3 I I \\
\hline & & 48 & 312 & 460 & 336 & 95 & $24 \mathrm{I}$ & 163 \\
\hline
\end{tabular}

* Includes muscle and skeletal tissues, but not skin. Each figure represents the result obtained for one rat.

Measurement of the sp. ac. at one time after the injection is of only limited interest. In Table $\mathrm{I}_{3}$ are grouped together the results of two experiments in which the sp. ac. of free lysine was measured at one or more intervals. In $A$ the values from Table 12 are summarized, to show more clearly the pattern of change with time; $B$ shows the results obtained from samples of tail blood taken at intervals after the injection.

It is clear from the results of others (Henriques, Henriques \& Neuberger, 1955; Humphrey \& Sulitzeanu, 1958; Gaetani et al. I96I) that in the first few minutes after the injection of a labelled amino acid the sp. ac. of the free amino acid falls extremely rapidly from an initial very high level. By $6 \mathrm{~h}$ the rate of fall has become relatively slow. In the experiments described here, between 6 and $24 \mathrm{~h}$ the sp. ac. decreased on 
the average by only $33 \%$, and between 24 and $48 \mathrm{~h}$ by $37 \%$. After $48 \mathrm{~h}$, judged by the values for serum, the sp. ac. became fairly stable. Since the number of samples was small, we do not attach any significance to the fact that in the depleted animals the initial sp. ac. were lower than in the controls.

Table 13. Specific activity (counts/min $\times \mathrm{10}^{3}$ per $\mu$ mole) of free lysine in rats at different times after injection of $\mathrm{L}-\left[U_{-}{ }^{14} C\right]$ lysine

\begin{tabular}{|c|c|c|c|c|c|c|c|}
\hline & & & & & $\begin{array}{l}\text { of } \mathrm{fr} \\
\text { after ir }\end{array}$ & sine at & \\
\hline & Before & After & & & - & - & -1 \\
\hline & injection & injection & Tissue & 6 & 24 & 48 & 72 \\
\hline$A$ & Stock & Stock & Mean of 6 tissues & $2 \cdot 53$ & $\mathrm{I} \cdot 88$ & $I \cdot \mathbf{2 3}$ & -- \\
\hline & $\begin{array}{l}\text { Protein-free } \\
3 \text { days }\end{array}$ & Protein-free & Mean of 6 tissues & $I \cdot 8 \mathrm{I}$ & $1 \cdot 66$ & $I \cdot 24$ & - \\
\hline$B$ & Stock & Stock & Serum & $I \cdot 46$ & 0.75 & 0.28 & 0.29 \\
\hline & $\begin{array}{c}\text { Low-protein } \\
5-8 \text { weeks }\end{array}$ & Low-protein & Serum & 0.84 & 0.43 & 0.35 & 0.37 \\
\hline
\end{tabular}

In $A$ the figures for the different time intervals were obtained with different rats. Each figure represents the value for one rat.

In $B$ the figures for the different time intervals were obtained with the same rats. Each figure represents the mean of results for three rats.

Table 14. Ratio of specific activities of protein-bound to free lysine in the muscle of rats killed 3 days after an injection of $\mathrm{L}-\left[U-{ }^{14} C\right] l y s i n e$

\begin{tabular}{|c|c|c|c|c|}
\hline \multicolumn{5}{|c|}{ (Each value is mean with its SD) } \\
\hline \multicolumn{2}{|c|}{ Diet } & \multirow{2}{*}{\multicolumn{3}{|c|}{ Ratio, sp. ac. of protein-bound lysine: free lysine }} \\
\hline Before & After & & & \\
\hline injection & injection & Expt I & Expt 2 & Expt 3 \\
\hline Stock & Stock & $0.61 \pm 0.19$ & $0.15 \pm 0.022$ & $0.323 \pm 0.045(6)$ \\
\hline Stock & Protein-free & $0.28 \pm 0.09(4)$ & $0.14 \pm 0.008(3)$ & $0.32 \pm 0.025(2)$ \\
\hline $\begin{array}{c}\text { Low-protein } \\
5-8 \text { weeks }\end{array}$ & Low-protein & $0.46 \pm 0.064(3)$ & $0.12 \pm 0.014(3)$ & $0.175 \pm 0.013(3)$ \\
\hline $\begin{array}{l}\text { Low-protein } \\
5-8 \text { weeks }\end{array}$ & Protein-free & $0.145 \pm 0.027(4)$ & $0.09 \pm 0.022(3)$ & - \\
\hline
\end{tabular}

Values in parentheses are the nos. of rats.

The significance of differences between treatments was calculated by the method given under Table 8 . The results were as follows:
Controls $v$. acute depletion.
Controls $v$. chronic depletion
Controls $v$. acute on chronic depletion
Acute depletion $v$. chronic depletion
$0.05>P>0.02$
$P=0.02$
$0.01>P>0.001$
Acute depletion $v$. acute on chronic depletion $\quad P=0.001$
Chronic depletion $v$. acute on chronic depletion $0.00 \mathrm{I}>P$.

\section{Specific activity of protein-bound lysine in muscle in relation to that of free lysine}

The ratio of the sp. ac. of protein-bound to that of free amino acid may be used for comparative purposes as a rough measure of the rate of protein synthesis. The figures obtained for muscle are shown in Table I4. In Expt 2 all the values were low, for reasons that are not clear. It is possible that the low uptake by muscle even in the animals on a normal diet could have been caused by an undetected infection. In one rat, which apparently had a mild respiratory infection, there was virtually no uptake 
of labelled lysine into muscle, serum or liver protein. This rat has been excluded from the series. In Expt 3 there is a large difference in the ratio in the chronically depleted animals compared with the controls. In contrast to the results in Expt I, there was no reduction in the ratio in the two animals acutely depleted of protein.

In principle it would be much more satisfactory to calculate the flux of free amino acid into protein by measurement of the sp. ac. of protein-bound and free amino acid at two different intervals (Lajtha, Furst, Gerstein \& Waelsch, 1957). This was attempted in one experiment in two groups of three rats. One group was on a normal diet throughout, the other on a protein-free diet for 3 days. Biopsies of muscle were taken $6 \mathrm{~h}$ after the injection, and further samples after another $24 \mathrm{~h}$. The results are shown in Table $\mathbf{r}_{5}$.

Table $1_{5}$. Flux* of lysine into muscle protein after an injection of $\mathrm{L}-\left[U-{ }^{14} \mathrm{C}\right]$ lysine in rats receiving a stock diet or a protein-free diet for 3 days before the injection until death

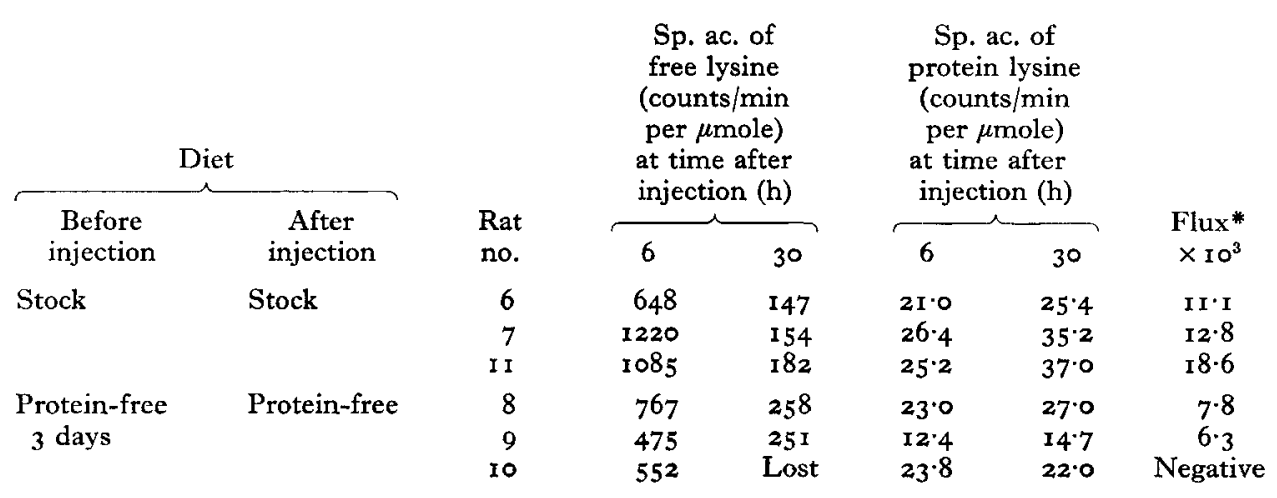

* Flux = increase in sp. ac. of protein-bound lysine between 6 and $30 \mathrm{~h} / \mathrm{mean} \mathrm{sp}$. ac. of free lysine between 6 and $30 \mathrm{~h}$.

Counts corrected for dose and body-weight.

It is difficult to design a satisfactory experiment of this type after a single injection of labelled amino acid because the rate of uptake of radioactivity by muscle protein is not linear. As the table shows, in the first few hours after the injection, when the sp. ac. of the free lysine is high, there must be a relatively large uptake of radioactivity. Once the sp. ac. of the precursor has fallen to a fairly steady level, i.e. after about $24 \mathrm{~h}$, the uptake is much slower and it then becomes difficult to detect differences between different treatments. In the experiment shown the sp. ac. of free lysine in the muscle at $6 \mathrm{~h}$ was higher than had been expected, and fell markedly during the next $24 \mathrm{~h}$. The arithmetic mean of the sp. ac. at these two times therefore does not present a true picture of the average precursor activity during the interval between the two samples. Nevertheless, an approximate estimate of the flux can be obtained from the mean activity. The difference between the two dietary groups is quite clear.

This type of experiment was felt to be inherently unsatisfactory, and was abandoned. It seemed more fruitful to try to produce a constant level of precursor activity by continuous infusion. Preliminary results of the work have been reported (Stephen $\&$ Waterlow, 1965). 


\section{DISCUSSION}

These experiments confirm the previous finding that, when a labelled amino acid is given to a protein-depleted animal, the distribution of radioactivity in the different tissues and organs of the body is not the same as in an animal which has received a normal protein intake. So far, studies have been made only with essential amino acids -methionine and lysine - and it is not known whether the same differences would be found with a non-essential amino acid. A preliminary report by workers in India who used labelled glycine suggests that with this amino acid also the distribution of radioactivity is affected by the protein content of the diet (Indian Council of Medical Research, 1963).

The question to be answered is whether the altered pattern of radioactivity reflects differences in the pattern of protein synthesis. Our first objective was to obtain more information about the sp. ac. of the free amino acid precursor, since it is obvious that measurement of the uptake of radioactivity into the protein cannot by itself give any indication of the amount of amino acid incorporated.

Attention was concentrated on muscle, which constitutes the largest protein mass in the body. If, therefore, the uptake of radioactivity in muscle is altered, this must inevitably affect the pattern of uptake in the body as a whole. The initial measurements of the effect of different dietary regimes on the distribution of body $\mathrm{N}$ suggested that in protein deprivation muscle $\mathrm{N}$ remained a fairly constant proportion of total body $\mathrm{N}$. This seems to be in contrast to the findings in man: in malnourished infants there is evidence from creatinine output during life (Standard, Wills \& Waterlow, I959), from muscle analysis (Waterlow \& Mendes, 1957) and from dissection after death (Kerpel-Fronius \& Frank, 1949) that the reduction in muscle mass is relatively greater than the reduction in body-weight. From the findings of Dickerson \& McCance (1964), the pig behaves more like man in this respect. This difference between man and rat fits in with the interesting suggestion of H. N. Munro ( I $^{6} 6_{5}$, personal communication) that in larger mammals such as man muscle may play a relatively more important part in the total amino acid metabolism of the body.

The low-protein diet apparently did not cause any reduction in free lysinc concentration in either muscle or liver. There are divergent results in the literature on the effect of diet on the free amino acid content of tissues. Thompson et al. (I950) found no change in the free lysine content of the liver, and a reduction of only $20 \%$ in that of muscle, in adult rats given a protein-free diet for 3 weeks. Roberts \& Simonsen ( 1962 ) summarize as follows their findings in rats starved for 9 days: 'We are thus faced with a situation in animal cells in which a variety of experimental conditions have been employed which probably have had great effects on turnover rates of free amino acids while having minimal effects on their steady-state concentrations.' On the other hand, Allison et al. $\left(196_{3}\right)$ found that a protein-free diet for 3 days caused very large falls in the free lysine concentration of both liver and muscle.

In the protein-depleted animals the sp. ac. of free lysine in muscle was not reduced. Admittedly these measurements were made for the most part at only one time-3 days after the injection - but the few observations made at earlier time intervals show 
no indication of a lower sp. ac. of free lysine in the tissues of rats given a low-protein diet than in those of controls. Since the concentrations of free lysine in the tissues were not significantly different in the two groups of animals, one would expect the sp. ac. (corrected for dose and body-weight) to be the same unless there was a change in total lysine turnover. We have shown elsewhere (Stephen \& Waterlow, 1965) that the lysine turnover is reduced by $20-30 \%$ in protein-depleted rats. This would tend to increase the sp. ac. of free lysine because of a decreased uptake into protein, but the amino acid turnover rate is so fast that the effect would probably only be apparent in the first few hours after the injection.

Henriques et al. (1955) suggested, from results obtained with labelled glycine, that in muscle there is a permeability barrier to the entry of free amino acids. We have confirmed this in experiments in which labelled lysine was infused at a constant rate over periods of several hours (Stephen \& Waterlow, 1965). Some indication was obtained that in protein-depleted animals the rate of entry of lysine into muscle was reduced. However, there is no evidence that this could limit the rate of protein synthesis. The fact that the amount, the concentration ratio and the sp. ac. of free lysine in muscle are no lower in protein-depleted than in normal rats, and are if anything higher, suggests that muscle protein synthesis is not limited by the availability of free amino acids within the cell.

The ratio, sp. ac. of protein-bound lysine:sp. ac. of free lysine can be regarded as a measure of the amount of lysine incorporated. The results obtained on samples of muscle were rather variable, but on the average the ratio was reduced in the proteindepleted rats, particularly in those with acute superimposed on chronic depletion. Similar results were obtained by Gaetani et al. (196I) in measurements made during the first hour after the injection of labelled lysine.

We conclude therefore that the low-protein diet led to a real decrease in the rate of amino acid uptake into muscle protein. The experiments on the fractionation of muscle, crude though they are, suggest that both the main types of muscle proteinsarcoplasmic and fibrillar-are more or less equally affected.

How this change is brought about is at present a matter of speculation. Our results seem to show that 3 days of acute protein deprivation did not regularly produce a full response. The chronically depleted animals had been on the low-protein diet for 6 weeks or more. Clearly observations should be made at shorter time intervals. It is a reasonable supposition that the response might be under endocrine control, and a case could be made for insulin as the active agent. Insulin stimulates the incorporation of amino acids by muscle protein (Manchester \& Young, 1958; Kostyo, I959; Manchester \& Wool, I963). In vitro the uptake of labelled amino acids by diaphragm is reduced by starvation, increased by refeeding, and it has been suggested that these changes are caused by variations in insulin activity (Wool, I960). Although the lowprotein diets given to the rats in our experiments had a high carbohydrate content, the food intake was reduced, so that the stimulus to insulin production might well be less than normal. Platt, Heard \& Stewart (1964) have produced evidence of decreased insulin activity in young pigs on a low-protein diet.

It was found that in the protein-depleted rats the skin lost even more $\mathrm{N}$ than did 
muscle. There was, however, an important difference between the two tissues in their mechanism of $\mathrm{N}$ loss. As was pointed out above, in muscle the rate of protein synthesis seems to be reduced to about the same extent in the two main protein fractions. In the skin, on the other hand, there was found to be a selective decrease in the incorporation of labelled amino acid in a fraction that consists mainly of collagen. This fits in with the observation that in both animals and man the urinary excretion of hydroxyproline peptides is decreased whenever there is failure of growth (Jasin, Fink, Wise \& Ziff, I 962 ; Picou, Alleyne \& Seakins, I965). It is thought that the hydroxyproline peptides in the urine originate as a by-product of collagen synthesis. The reduction in hydroxyproline excretion therefore probably indicates a decreased rate of collagen synthesis. Since in the undernourished animal the collagen content of many tissues is increased (Mendes \& Waterlow, 1958; Montgomery, r962; Čabak et al. 1963), one must conclude that there is also a reduced rate of collagen breakdown. This, however, probably varies according to tissue and species. The work of Cabak et al. ( $\left.{ }^{196} 6_{3}\right)$ indicates that in the rat the collagen of skin is more labile than that of muscle or bone. It seems that in the rat the skin must play a very important part in overall protein metabolism. In man it may be less important, because of the smaller ratio of surface to volume. It has been shown by analysis of cadavers of infants dying of malnutrition that there was no reduction in the total amount of collagen in the skin or in the body as a whole, compared with the amounts expected in a normal child of the same height (Picou, Halliday \& Garrow, 1966). Therefore in man skin collagen may be less labile and more inert than in the rat.

To obtain a more complete picture of the way in which the animal as a whole adapts to deprivation of protein, it is necessary to consider also the reaction of the internal organs, and particularly of the liver. Many previous workers have shown in experiments with labelled amino acids that in rats on a low-protein diet the liver protein becomes more highly labelled. The only exception that we know of is provided by the work of Kean (1959), who in experiments with $\left.{ }^{35} \mathrm{~S}\right]$ methionine found a decreased uptake of radioactivity in liver protein in rats given a low-protein diet. In the experiments presented now no direct observations were made which would give information about the rate of amino acid incorporation in the liver. To determine this rate it is necessary to make measurements in the first few hours or even minutes after the injection, before the radioactivity of the liver proteins has reached its peak. Experiments of this kind have been made by Gaetani et al. (196r), who showed very clearly that after the injection of labelled lysine the ratio of sp. ac. of protein-bound lysine to sp. ac. of free lysine was higher in rats fed on a protein-free diet than in those fed normally, suggesting an increase in the rate of protein synthesis. Results obtained in our preliminary experiments, by the continuous infusion method, show that in protein-depleted rats the rate of synthesis of mixed liver proteins is normal or only slightly reduced, whereas that of muscle proteins is greatly reduced. The liver therefore reacts in a way opposite to that of muscle, and it is of interest that at least two hormones - insulin and cortisone-have an opposite influence on protein metabolism in these two tissues. Insulin causes a decrease in amino acid uptake by liver, and increase by muscle, whereas the effect of cortisone is the reverse in both tissues. 
Of great interest in this connexion are some recent observations on the effect of the protein content of the diet on the activity of certain liver enzymes. Schimke (I962) has shown that on a protein-free diet the activity of most of the urea-cycle enzymes is reduced. Spadoni and co-workers (Mariani, Spadoni \& Tomassi, 1963; Gaetani, Paolucci, Spadoni \& Tomassi, r 964) found that a low-protein diet causes an increase in the activity of amino acid-activating enzymes in the liver. The effect of these two changes must be that a free amino acid molecule in the liver cell, whether it has come from the food, from the katabolism of extrahepatic protein, or from that of liver protein, will have a smaller chance of being degraded to urea, and a greater chance of being re-incorporated into protein. This provides a reasonable explanation for the apparent paradox, that in the protein-deficient animal the incorporation of radioactivity in the liver occurs at a normal or greater than normal rate, but the loss of radioactivity is very much slowed down (Solomon \& Tarver, 1952). Because of this slower loss, it has been supposed that on a low-protein diet the turnover of liver protein, like that of plasma proteins, is reduced. We suggest that on the contrary the turnover is normal or even increased; at the same time there is much more efficient re-utilization of labelled amino acids liberated by katabolism.

As with muscle, the question must arise of how these events are set in motion. In the last analysis the controlling factor must be the rate of entry of amino acids from the food. There seems to be a contradiction between our finding that there is no significant difference between normal and protein-depleted rats in the sp. ac. or concentration of free lysine in liver or muscle, and the conclusion reached by Munro (Munro \& Mukerji, 1958, 1962) that the mechanisms of protein synthesis are very sensitive to variations in the amino acid supply. Moreover, the liver cell is presumably unable to distinguish between an amino acid provided by the food and one made available as the result of protein katabolism. Our results by the constant infusion method (Stephen \& Waterlow, 1965) indicate that in the normal rat the total $\mathrm{N}$ turnover from katabolism is approximately $350 \mathrm{mg} \mathrm{N} / \mathrm{I} 00 \mathrm{~g}$ rat daily. A normal diet would supply about $250-300 \mathrm{mg} \mathrm{N} / \mathrm{I} 00 \mathrm{~g}$ daily, so that the total amount of $\mathrm{N}$ entering the free amino acid pool would be about $600 \mathrm{mg} / \mathrm{roo} \mathrm{g}$ daily. A reduction of $80 \%$ in the intake from food, from 250 to $50 \mathrm{mg} \mathrm{N} /$ day would reduce the total amount of amino $\mathrm{N}$ entering the pool by only $30 \%$, from 600 to $400 \mathrm{mg} /$ day, unless there is a concomitant fall in total turnover. Thus the response to variations in amino acid supply must indeed be very sensitive. Perhaps an appropriate analogy would be that in a motor car the carburettor at any given moment contains roughly the same amount of petrol, but the distance travelled in a day will reflect very accurately the average rate of fuel supply.

The young rat can exist on a low-protein diet such as we have used for long periods without either much gain or loss in weight (Mendes \& Waterlow, 1958). There is clearly an adaptation to the low-protein intake. Our results suggest that this adaptation involves an alteration in the pattern of protein turnover. Turnover is maintained at more or less normal levels in those organs which may be considered most essential for life, at the expense of those, such as muscle and skin, which are less essential. This adaptation was aptly foreshadowed by Garrow (1959) in the phrase 'contraction of metabolic frontiers'. 


\section{REFERENCES}

Addis, T., Poo, L. J. \& Lew, W. (1936). F. biol. Chem. Ir5, I 1 7.

Allison, J. B., Wannemacher, R. W. Jr \& Banks, W. L. Jr (1963). Fedn Prac. Fedn Am. Socs exp. Biol. 22, 1126.

Barry, J. M. (1952). F. biol. Chem. 195, 795.

Bendicenti, A., Mariani, A., Paolucci, A. M. \& Spadoni, M. A. (1959). Boll. Soc. ital. Biol. sper. 35, 1997.

Bidinost, L. E. (195I). F. biol. Chem. 190, 423.

Bonsnes, R. W. \& Taussky, H. H. (1945). F. biol. Chem. 158, 581.

Cabak, V., Dickerson, J. W. T. \& Widdowson, E. M. (1963). Br. F. Nutr. 17, 6or.

Christensen, H. N., Streicher, J. A. \& Elbinger, R. L. (1948). F. biol. Chem. 172, 515.

Dickerson, J. W. T. (1960). Biochem. F. 75, 33 .

Dickerson, J. W. T. \& McCance, R. A. (1964). Clin. Sci. 27, 123.

Gaetani, S., Mariani, A., Spadoni, M. A. \& Tomassi, G. (1961). Boll. Soc. ital. Biol. sper. 37, 1685.

Gaetani, S., Paolucci, A. M. Spadoni, M. A. \& 'Tomassi, G. (1964). J. Nutr. 84, 173.

Garrow, J. S. (1959). F. clin. Invest. 38, $244 \mathrm{I}$.

Garrow, J. \& Piper, E. A. (1955). Biochem. J. 60, 527.

Hagan, S. N. \& Scow, R. O. (1957). Am. F. Physiol. 188, 9 r.

Henriques, O. B., Henriques, S. B. \& Neuberger, A. (I955). Biochem. F. 60, 409.

Humphrey, J. H., Neuberger, A. \& Perkins, D. J. (1957). Biochem. F. 66, 390.

Humphrey, J. H. \& Sulitzeanu, B. D. (1958). Biochem. F. 68, 146.

Indian Council of Medical Research (1963). Rep. Indian Coun. med. Res. 1962-3, p. Io.

Jagenburg, O. R. (1959). Scand. F. clin. Lab. Invest. II, Suppl. 43, p. I.

Jasin, H. E., Fink, C. W., Wise, W. \& Ziff, M. (1962). J. clin. Invest. 4I, 1928.

Kean, E. A. (1959). Q. $尹 l$ exp. Physiol. 44, 35 I.

Kerpel-Fronius, E. \& Frank, K. (1949). Annls Paediat. 173, 32 I.

Kostyo, J. L. (1959). Nature, Lond. $183,{ }_{5} \mathbf{1 8}$.

Lajtha, A., Furst, S., Gerstein, A. \& Waelsch, H. (1957). F. Neurochem. I, 289.

Leach, A. A. (1960). Biochem. F. 74, 70.

Manchester, K. L. \& Wool, I. G. (1963). Biochem. F. 89, 202.

Manchester, K. L. \& Young, F. G. (1958). Biochem. F. 70, 353.

Mariani, A., Spadoni, M. A. \& Tomassi, G. (1963). Nature, Lond. 199, 378.

Mendes, C. B. (1959). Studies on the composition of muscle of weanling rats after protein depletion and repletion. $\mathrm{PhD}$ Thesis, University of London.

Mendes, C. B. \& Waterlow, J. C. (1958). Br. F. Nutr. 12, 74.

Montgomery, R. D. (1962). Y. clin. Path. 15, 51 r.

Munro, H. N. \& Mukerji, D. (1958). Biochem. F. 69, 32 I.

Munro, H. N. \& Mukerii, D. (1962). Biochem. F. 82, 520.

Muramatsu, K., Sato, T. \& Ashida, K. (1963). F. Nutr. 8r, 427.

Penn, N. W., Mandeles, S. \& Anker, H. S. (1957). Biochim. biophys. Acta 26, 349.

Picou, D., Alleyne, G. O. A. \& Seakins, A. (1965). Clin. Sci. 29, 517.

Picou, D., Halliday, D. \& Garrow, J. S. (1966). Clin. Sci. 30, 345.

Platt, B. S., Heard, C. R. C. \& Stewart, R. J. C. (1964). In Mammalian Protein Metabolism. Vol. 2, Chapter 2 I, p. 446. [H. N. Munro and J. B. Allison, editors.] New York and London: Academic Press Inc.

Roberts, E. \& Simonsen, D. G. (1962). In Amino-acid Pools, p. 334. [J. T. Holden, editor.] Amsterdam: Elsevier.

Schimke, R. T. (1962). J. biol. Chem. 237, I921.

Schreier, K. \& Kazassis, C. (1960). Nature, Lond. 187, I117.

Sendroy, J., Jr (1937). \%. biol. Chem. 120, 405.

Solomon, G. \& Tarver, H. (1952). F. biol. Chem. 195, 447.

Standard, K. L., Wills, V. G. \& Waterlow, J. C. (1959). Am. F. clin. Nutr. 7, 27 I.

Stephen, J. M. L. \& Waterlow, J. C. (1965). F. Physiol., Lond. 178, 40P.

Thompson, H. T., Schurr, P. E., Henderson, L. M. \& Elvehjem, C. A. (1950). Y. biol. Chem. 182, 47.

Waterlow, J. (1959). Nature, Lond. 184, 1875.

Waterlow, J. C. (1962). In Protein Metabolism. [F. Gross, editor.] Berlin: Springer-Verlag.

Watcrlow, J. C., Cravioto, J. \& Stephen, J. M. L. (1960). Adv. Protein Chem, I5, 131.

Waterlow, J. C. \& Mendes, C. B. (1957). Nature, Lond. 180, г36r.

Widdowson, E. M. \& McCance, R. A. (1956). Br. F. Nutr. 1o, 363.

Wilmer, H. A. (1940). Proc. Soc. $\exp$ Biol. Med. 43, 545.

Wool, I. G. (1960). Am. Y. Physiol. 198, 357. 